\title{
Measures to assess well-being in low-carbon-dioxide cities
}

Christopher T. Boyko BA, MA, PhD, AHEA Senior Research Associate, Lancaster University, Lancaster, Lancashire, UK
2 Rachel Cooper PhD, OBE

Professor, Lancaster University, Lancaster, Lancashire, UK

3 Cary Cooper BS, MBA, PhD, FAcss, CBE

Professor, Lancaster University, Lancaster, Lancashire, UK
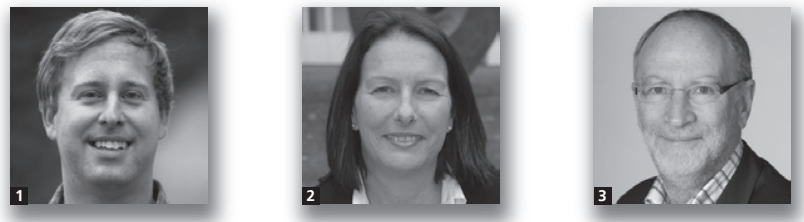

Policies aimed at reducing carbon dioxide emissions often focus on the need to change existing behaviours and social practices as well as to provide technological advances in energy supply, waste, transport, industry and infrastructure. While fundamentally important to the mitigation of climate change, little is written about the impact that achieving carbon dioxide reduction targets, particularly for the built environment, will have on individual and societal well-being and quality of life. This paper investigates how a set of measures can be developed to assess well-being in cities, both as they are at present and as they transition to 'low-carbon-dioxide' futures. It outlines the important relationship between well-being, low-carbon-dioxide development and the built environment. $\mathrm{A}$ strategy for obtaining and assessing well-being measures is explained, the measures are discussed and 100 selected measures are detailed. The paper ends by illustrating how these measures can be integrated into a wider study of well-being.

\section{Introduction}

With the introduction of the Climate Change Act in 2008 and a plan to transition to a low-carbon-dioxide country in 2009 , the UK government began developing a route map that focused on emissions reductions, resource security, economic opportunities and the protection of vulnerable groups (Climate Change Act 2008, 2008; DECC, 2009). The UK is not alone in this endeavour; many countries have formulated, or are beginning to consider formulating, policies around the 'lowcarbon' and climate change agendas, and are setting targets for reducing the amount of non-renewable fossil fuels they use (Ellis et al., 2009), and transitioning to low-carbon futures (Bulkeley et al., 2013). Numerous cities and local governments also have signed up to reduce their carbon dioxide emissions (Bailey et al., 2012; Dhakal and Shrestha, 2010; Gomi et al., 2010; LSE Cities, 2012).

To achieve the IPCC (2007) $80 \%$ carbon dioxide reduction targets in the developed world, scientists, policymakers, advocates and academics suggest that technological, societal and behavioural changes will need to occur (e.g. greater investment in low-carbon infrastructure, and reconsidering governance systems) (DECC, 2009; Platt et al., 2011; Urry, 2011, 2013). While such adaptations to the way we live may result in carbon dioxide reductions, there is uncertainty regarding the impact on our quality of life, and individual and societal wellbeing. To date, this issue has only been discussed at the conceptual level and using anecdotal case studies, and has not been explored empirically (see Aked et al., 2010; Cabe, 2009a, 2009b, 2009c; Urry, 2011). Through original research from the UK Engineering and Physical Sciences Research Council (EPSRC)-funded 'Liveable Cities' programme grant, the authors aim to provide empirical evidence that suggests a relationship between transitioning to a low-carbon future and well-being within cities, and offers a way of measuring the impact.

This paper first provides definitions for relevant terms and outlines the literature on well-being as it relates to the built environment and low-carbon development. The research strategy for gathering and selecting well-being measures is explained next. The measures are then introduced and explained in more detail. The authors' 100 measures are shown in the final section, with a discussion of shortcomings 


\section{Offprint provided courtesy of www.icevirtuallibrary.com Author copy for personal use, not for distribution}

and about how the measures can be - and are being - incorporated into research on well-being in cities.

\section{Definitions}

For the purposes of this paper, the following key terms are defined and clarified.

'The built environment' refers to objective and subjective characteristics of the physical context in which people spend their time, including aspects of urban design, land use and transportation. It also shapes and is shaped by patterns of human activity (adapted from Davison and Lawson, 2006; Handy et al., 2002). Two built environment scales that are relevant for this paper are the 'city' - the product of a socioorganisational process of urbanisation (Harvey, 1996) that is expressed territorially as well as economically, socially, politically and ecologically (Park, 1925) - and the 'neighbourhood' - 'a delineated area within physical boundaries where people identify their home and where they live out and organise their private lives' (Power and Bergin (1999), p. 9; see also Kearns and Parkinson (2001) for a discussion of the multiscalar nature of neighbourhoods).

'Low-carbon development' involves addressing and integrating climate change into traditional planning and development objectives to propose development solutions that have lower emissions trajectories (Morita et al., 2001).

'Low-carbon city' is an urban model, much like the eco-city or the smart city, that emphasises compactness and mixed use alongside significantly reduced, carbon-dioxide-intensive energy consumption and minimal greenhouse gas emissions. Based on principles of sustainable urban development, it also underscores the use of finite resources as well as the reuse of resources where possible, and endeavours to achieve homeostasis with the ecosystem (Lehmann, 2015.)

'Well-being' may be described as a positive physical, social and mental state that occurs when several basic needs are met (e.g. education or shelter) and one perceives a sense of purpose, including being able to achieve important personal goals and take part in society (Defra, 2010).

\section{The relationship between well-being, the built environment and low-carbon development}

A number of reviews have been published in the past few years that highlight the correlational (and sometimes causal) relationship between well-being and the built environment (see Anderson, 2013; Bowler et al., 2010; Codinhoto et al., 2009; Cooper et al., 2008, 2011; Day et al., 2000; Daykin and Byrne, 2006; Devlin and Arneill, 2003; Evans et al., 2003; Joseph, 2006; Kaczynski and Henderson, 2007; Lawton, 2001;
Staricoff et al., 2003; Staricoff, 2004; Teresi et al., 2000; Ulrich et al., 2004; Weinstein, 2001; Wells, 2000). Much of the relational evidence presented tends to focus on negative aspects, such as poor-quality housing, noise, damp, air quality, temperature, pollution and fear. Thus, in most, but not all, cases, people have experienced distress, depression and elevated levels of stress from being exposed to the above variables. However, there are studies that concentrate on positive aspects (e.g. exposure and access to nature (Kaplan, 2001; Kuo, 2001; Van den Berg et al., 2003; Wells and Evans, 2003; see Cooper et al., 2008, for additional studies)).

Much less has been written about the three-way relationship between well-being, the built environment and low-carbon development. This may be because low-carbon development is a relatively recent phenomenon and greater emphasis has been placed on how cities, countries and the planet will adapt to uncertain futures, rather than to how adaptation will affect citizens' well-being. Nonetheless, discussion around the impacts of embodied carbon in building materials and the carbon footprint of our built environment has prompted questions about what can be done to reduce the impact of carbon on the environment, the economy and people's lives (Aked et al., 2010; WHO, 2011). With current examples, such as BedZED (Beddington Zero Energy Development) in Sutton, UK (Aked et al., 2010), suggesting that low-carbon developments also can foster social interaction, there are ways to design the built environment so that it responds to climate change and also helps with social (and economic and environmental) issues to engender more efficient, resilient places (Cabe, 2009c).

Within the field of healthcare, Cabe (2009a, 2009b, 2009c) has shown that thinking wisely about the physical fabric of cities and neighbourhoods can broadly improve public health. Doing so within a low-carbon development framework - while difficult to accomplish due to the often-competing motives of decision-makers and stakeholders, the cost of infrastructure adaption and the willingness of stakeholders to change behaviours - also may have positive implications for well-being (Community Health Partnerships, 2008). However, if development continues in a business-as-usual fashion, the built environment in cities may exacerbate already-existing problems (e.g. increased carbon dioxide emissions from private transport), thus increasing the likelihood of costly mitigation (Stern, 2006), and facilitating a decrease in well-being and quality of life.

Although this three-way relationship is being discussed within the built environment and healthcare sectors to some extent and other industries are beginning to take notice, there is a lack of concrete testing and empirical evidence to demonstrate that transitioning to a low-carbon built environment also positively impacts well-being. In the next section, the authors 


\section{Offprint provided courtesy of www.icevirtuallibrary.com Author copy for personal use, not for distribution}

discuss their approach for empirically assessing well-being within built environments, and whether features of low-carbon development support better well-being and quality of life among residents.

\section{Research strategy}

The authors followed the four-step process of Coombes and Wong (1994) for systematically determining the selection of well-being measures: step 1, conceptual consolidation; step 2, analytical structuring; step 3 , indicator identification; and step 4 , index creation. In step 1 (conceptual consolidation), the basic concept to be studied - well-being - was undertaken through literature reviews before proceeding to step 2. For this step (analytical structuring), the authors began their methodical search of well-being and well-being-related measures by using an online search engine. Terms, such as 'well-being', 'happiness', 'quality of life', 'life satisfaction', 'questionnaire', 'survey', 'checklist', 'inventory', 'scale', 'index', 'indicator' and 'measure' were entered into the search engine, including plural forms of relevant words. In addition, the authors knew of several surveys that are or were being administered, so included them in their list of measures. Finally, through a review of the academic literature on well-being, several surveys were referenced, and added to the list. From this search, 2288 measures from 98 different sources were found and collated.

With all of the measures added to an Excel spreadsheet, the authors moved to step 3 (indicator identification), where they reduced the number to a feasible amount, as the idea is to use a set of measures to assess well-being in cities, both as they are now and in low-carbon scenarios. Reducing the amount involved rigorously assessing each measure and deciding if it was related to well-being, the built environment and lowcarbon development. To do this, the authors looked to four influential sources - Aked et al. (2010) and Cabe (2009a, $2000 \mathrm{~b}, 2000 \mathrm{c}$ ) - and found 30 issues that could be grouped together in two, relevant, built environment scales (12 at home/ building scale and 18 at neighbourhood/city scale):

\section{Home/building scale}

- Use service space efficiently.

- Use renewable energy and sustainable materials.

- Use passive design techniques.

- Consider weather and temperature fluctuations.

- Use interesting and local architectural design.

- Is comfortable rather than institutional.

- Put people in contact with the natural environment.

- Exploit natural light, and use natural ventilation wherever possible.

- Create places with strong identity and local character to promote feelings of place attachment.
- Make services accessible and efficient.

- Design adaptable accommodation.

- Improve staff recruitment and retention, and increase morale.

Neighbourhood/city scale

- Develop a city-wide hierarchy of acute primary and community health facilities that join up delivery of services from hospital to home alongside other public amenities and public transit infrastructure.

- Create inclusive, accessible places with relevant services that encourage travel by foot, bicycle or public transport and that discourage motor traffic.

- Green space - and, indeed, all public spaces - should be budgeted, planned and carefully designed.

- Keep green spaces public, not privatised.

- Integrate city-wide networks of planting and green infrastructure.

Encourage organised activities in parks and open spaces.

- Provide quality play spaces for all ages.

- Use programmed activities in well-designed and maintained public spaces to increase local pride, sense of safety and neighbourhood identification.

- Create social hubs and spaces for social networking and interaction.

- Facilitate interaction with street layouts.

- Avoid blank frontages.

- Position windows to overlook public routes and spaces.

- Use good street lighting.

- Develop shared energy resources.

- Use traffic calming measures to reduce traffic speeds in residential and built-up areas.

- Use home zones to prioritise pedestrian movement and make communities less dominated by traffic.

- Ensure pedestrian and cycling routes connect local services to residential development.

- Use interesting and local urban design features.

The above issues - found in some of the definitions for wellbeing, the built environment and low-carbon development/ cities at the beginning of this paper, as well as in the relevant literature - were added to the Excel spreadsheet as columns, acting as criteria for selecting relevant measures, which were in separate rows. For each measure to be considered relevant, it had to address an appropriate number of criteria. Since some measures were better represented at one scale as opposed to another scale, the total number of criteria addressed may be low. However, at one scale, the measure might have addressed many criteria; thus, it would be selected. Those measures that overlapped both scales and addressed many criteria at both scales also would have been selected. 
Before the measures were selected outright, the authors asked two more questions.

- Is the measure duplicated by another measure in the category (e.g. 'life expectancy' and 'healthy life expectancy')?

- Will the data for the measure be easy to collect (e.g. found on a government website)?

The first question allowed the authors to group similarsounding measures together and to make a decision about how best to word the measures for the sake of obtaining data about the well-being of cities. Responses to the second question meant that the authors would end up selecting those measures that overlapped with many of the criteria and which also could be found without too much trouble. One limitation to selecting measures in this manner is that data for more difficult to obtain measures - measures that might uncover richer, more interesting aspects about the well-being of people in cities might not be collected.

Finally, in an effort to group the measures together, rather than create a large list based on the above analysis, the authors moved to step 4 (index creation) and created an index of categories. Like the measures, the categories were analysed to ensure that they made sense, responding to the following question and sub-questions.

(a) Does the category make sense?

(i) Can the category fit into another category?

(ii) Should the category be split into one or more categories?

(iii) Does the category fit with the well-being, built environment and low-carbon agenda?

(iv) Does the measure fit the category?

Based on the above questions, 30 categories were created and 21 were used in taking forward the 100 measures.

\section{The well-being measures in more detail}

The 2288 measures were selected from 98 different sources from around the world that were measuring some aspect of wellbeing, happiness and/or quality of life. The sources ranged from those measuring well-being across countries (i.e. at the international scale) to those measuring well-being among individuals (i.e. at the sublocal scale). In three cases, sources overlapped at more than one scale (e.g. the North West Mental Well-being Survey contains questions at both regional and local scales).

From examining the different sources, over a third of the measures were found at the sublocal scale. These sources are often used by psychologists, psychiatrists and other healthcare professionals to understand how a client or patient is doing in terms of their mental health and well-being. The next most

\begin{tabular}{lrl} 
Scale range & Count & Example \\
\hline International & 20 & Eurobarometer \\
National & 29 & Well? What do you think? \\
Regional/local & 1 & North West Mental Well-being Survey \\
Subregional & 1 & Illinois State Civic Index \\
Local & 7 & Place Survey \\
Local/sublocal & 2 & Well-being and Resilience Measure \\
Sublocal & 38 & Life Satisfaction Index
\end{tabular}

Table 1. Scale at which well-being measures were selected

frequent scale was national, with many countries creating their own surveys to measure well-being. The third most frequent scale was international. Here, international bodies and organisations measure well-being and compare results across different countries or larger administrative boundaries. The remainder of the sources were found between sublocal and national scales, at local/sublocal, subregional and regional/local scales (see Table 1).

Further analysis of the well-being measures revealed that approximately $75 \%$ were subjective; that is, the measures asked about feelings, life experiences, judgements and preferences (Dolan et al., 2011; House of Commons Environmental Audit Committee, 2012; Michaelson et al., 2012). The remaining 25\% were objective measures, which refer to evaluations of the social context using measurable criteria (Dolan et al., 2006, 2011; Houses of Parliament, 2012) that are independent of a person's perceptions (Weden et al., 2008). Asking about a person's fear of crime in their neighbourhood is an example of a subjective measure; whereas, calculating actual crime rates in that same neighbourhood is an example of an objective measure.

In terms of the audience that the sources wished to target, the authors determined that $87 \%$ did not specify any demographic. That is, most sources did not direct their well-being measures at one or more audience. When the sources with no unspecified audience were removed from the equation, the following observations were made

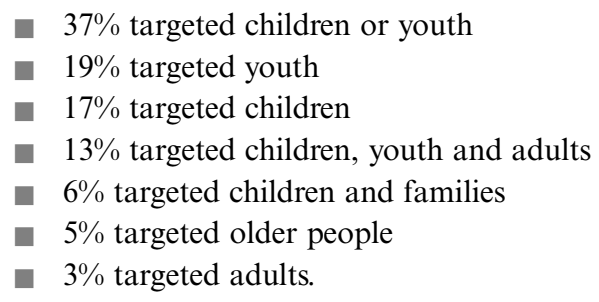

Thus, of the $13 \%$ of sources that aimed to understand the wellbeing of a specific audience, $92 \%$ targeted children or youth in some way. This is not surprising, given the spotlight on community development programmes and initiatives that have 


\section{Offprint provided courtesy of www.icevirtuallibrary.com Author copy for personal use, not for distribution}

attempted to support children and youth since the 1950s (Coulton, 1995; Kubisch et al., 1995), and organisations that monitor inequality and disadvantage among children and families (e.g. the UK National Children's Bureau).

Finally, in an effort to understand which areas of well-being were most popular among the 98 sources, the authors divided all the measures into 30 categories and counted the frequency of measures in each category. Some of the same measures were used by different sources, whereas others were distinct, yet still fit into one of the categories (see Table 2).

Psychological health contained the most well-being measures, with nearly $30 \%$ of the total measures represented. As stated earlier, this may be due to the prevalence of measures at the sublocal scale that healthcare professionals, including psychologists and psychiatrists, use when assessing the wellbeing of patients and clients. The next most frequent category was social support (almost 10\% of the total measures), which is regarded as one of the main components of well-being (Defra, 2010; Fowler and Christakis, 2008; Government Office for Science, 2008); as such, there is likely to be great interest in better understanding how social support works in various contexts. The third most popular category was environment (representing approximately $9 \%$ of the total measures). As a result of the tangible nature of certain environmental features, such as the average concentration of particulate matter in cities, data from environmental measures may be collected more often than other, less concrete or valued measures.

Compared with the above, most of the remaining categories had relatively low quantities of well-being measures (i.e. less than $5 \%$ of the total measures; general health and community participation were exceptions with about 6 and $5 \%$, respectively). In fact, some categories, such as food, information and knowledge, morals, and private services, only had one or two measures within their respective categories. This latter finding suggests that there are current gaps in the way well-being is defined and measured that could be examined in more detail. A more plausible reason - and one that was confirmed by analysing the categories - is that some categories did not make sense or were incorporated into already-existing and meaningful categories.

\subsection{The measures used to assess well-being in (low-carbon) cities}

Upon analysing all the well-being measures against the 30 criteria mentioned in the research strategy section, 100 measures were selected: 50 subjective well-being measures and 50 objective well-being measures. In addition, from the 30 categories highlighted in Table 2, 21 categories were selected. The 100 measures represent those aspects of well-being that have a relationship with low carbon dioxide and the built environment (see Table 3).

\begin{tabular}{|c|c|c|}
\hline Category & $\begin{array}{c}\text { Frequency } \\
\text { of well-being } \\
\text { measure }\end{array}$ & $\begin{array}{c}\text { Percentage of } \\
\text { total well-being } \\
\text { measures: \% }\end{array}$ \\
\hline Community participation & 122 & $5 \cdot 33$ \\
\hline Crime & 100 & $4 \cdot 37$ \\
\hline Demographics & 19 & 0.83 \\
\hline Domain-specific satisfaction & 66 & $2 \cdot 88$ \\
\hline Economy & 94 & $4 \cdot 10$ \\
\hline Education & 44 & 1.92 \\
\hline Employment & 41 & $1 \cdot 79$ \\
\hline Energy & 10 & 0.44 \\
\hline Environment & 199 & 8.69 \\
\hline Food & 1 & 0.04 \\
\hline General health & 146 & $6 \cdot 38$ \\
\hline General life satisfaction & 40 & $1 \cdot 76$ \\
\hline Governance & 6 & 0.26 \\
\hline Housing & 65 & $2 \cdot 84$ \\
\hline Information and knowledge & 1 & 0.04 \\
\hline Infrastructure & 4 & $0 \cdot 17$ \\
\hline Morals & 1 & 0.04 \\
\hline Physical health & 36 & $1 \cdot 57$ \\
\hline Planning & 9 & 0.39 \\
\hline Political participation & 87 & $3 \cdot 80$ \\
\hline Private services & 2 & 0.09 \\
\hline Psychological health & 679 & $29 \cdot 65$ \\
\hline Public services & 93 & $4 \cdot 06$ \\
\hline Social support & 226 & $9 \cdot 87$ \\
\hline Society and tolerance & 29 & $1 \cdot 27$ \\
\hline Spirituality & 6 & 0.26 \\
\hline Standard of living & 35 & $1 \cdot 53$ \\
\hline Transportation & 51 & $2 \cdot 23$ \\
\hline Work & 10 & 0.44 \\
\hline Work-life balance & 64 & $2 \cdot 79$ \\
\hline Total & 2228 & $100 \cdot 00$ \\
\hline
\end{tabular}

Table 2. The frequency and percentage of well-being measures per category

\section{Conclusions: how the measures can be integrated into a wider study about the assessment of well-being in (low-carbon) cities}

It is clear from this analytical review of measures that the concept of well-being is extremely broad and multi-dimensional, and that it is not feasible to use 2288 measures in any survey of well-being. Therefore, it is essential to focus the assessment of well-being on a specific intervention or location. The 100 well-being measures listed in Table 3 can be used to begin to explore how people feel about or perceive a range of topics relating to well-being (i.e. the subjective measures) as well as independent information about the places in which people live 


\begin{tabular}{|c|c|c|}
\hline Category & & ure \\
\hline Community participation & $\square$ & $\begin{array}{l}\text { How would you describe your sense of belonging to your neighbourhood? }{ }^{a} \\
\text { What sorts of things stop you from doing any activities you would like to do? } \\
\text { Percentage of people who feel they belong to their neighbourhood }\end{array}$ \\
\hline Crime & घ & $\begin{array}{l}\text { How safe do you feel walking alone in this area... after dark } ?^{a} \\
\quad \ldots \text { during the day? } \\
\text {... in [city] } ?^{a} \\
\text { It is safe to be out and about on the streets? }{ }^{a} \\
\text { Personal crime rate } \\
\text { Percentage of children who feel safe going to/from } X\end{array}$ \\
\hline Demographics & ש & Number of inhabitants \\
\hline $\begin{array}{l}\text { Domain-specific } \\
\text { satisfaction }\end{array}$ & च & 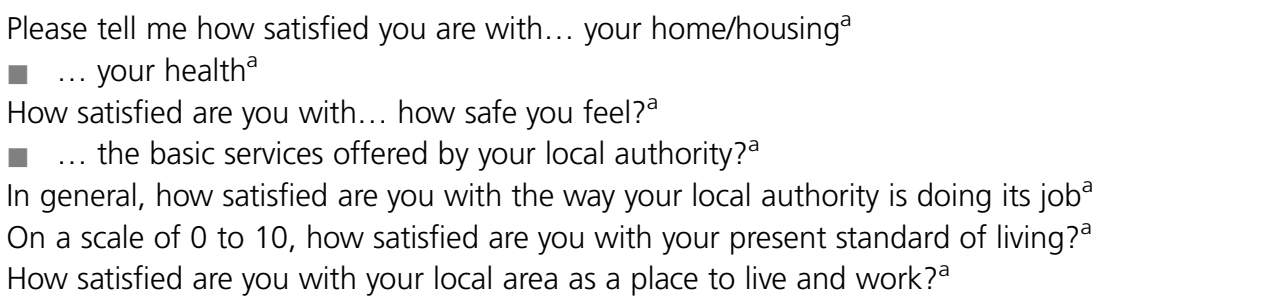 \\
\hline Economy & $\begin{array}{l}\mathbf{\square} \\
\mathbf{\square} \\
\mathbf{\square} \\
\mathbf{\square}\end{array}$ & $\begin{array}{l}\text { [City] spends its resources in a responsible way }{ }^{\text {a }} \\
\text { Household/family income } \\
\text { Wages for different demographics } \\
\text { Poverty rate } \\
\text { Private investment in dwellings }\end{array}$ \\
\hline Education & $\begin{array}{l}\mathbf{\square} \\
\mathbf{\square}\end{array}$ & $\begin{array}{l}\text { How happy are you about the school that you go to? } \\
\text { Literacy rate }^{\text {Haghest degree awarded }}\end{array}$ \\
\hline Employment & घ & $\begin{array}{l}\text { Unemployment rate } \\
\text { Percentage of the working age population in employment }\end{array}$ \\
\hline Energy & घ & $\begin{array}{l}\text { Greenhouse gas per household } \\
\text { Average total energy consumption of buildings } \\
\text { Energy consumption for transport }\end{array}$ \\
\hline Environment & $\begin{array}{c}\square \\
\mathbf{\square} \\
\mathbf{\square} \\
\mathbf{\square} \\
\mathbf{\square} \\
\mathbf{\square} \\
\mathbf{\square} \\
\mathbf{\square} \\
\mathbf{\square}\end{array}$ & $\begin{array}{l}\text { In your city or area where you live, are you satisfied or dissatisfied with the beauty or physical } \\
\text { setting? }^{a} \\
\text { It is important to me that I can be proud of my local environment }^{a} \\
\text { Do you live within a } 10 \text { min walk of a natural blue or green space? }{ }^{a} \\
\text { What do you think of the parks/play areas in your area? }{ }^{a} \\
\text { My local area is safe for children to play outside } \\
\text { [City] is committed to the fight against climate change } \\
\text { Average ecological footprint } \\
\text { Populations living in areas with, in relative terms, the least favourable environmental conditions } \\
\text { Percentage of wards in the } 10 \% \text { most deprived areas } \\
\text { Percentage of households satisfied with the quality of the places in which they live }\end{array}$ \\
\hline General life satisfaction & घ & $\begin{array}{l}\text { Overall, how... satisfied with your life were you } 5 \text { years ago }{ }^{a} \\
\ldots \text {... optimistic do you feel about the next } 5 \text { years? } \\
\text { All things considered, how satisfied or dissatisfied are you with your life as whole nowadays? } \\
\text { On which step of the ladder would you say you personally feel you stand at this time? }\end{array}$ \\
\hline
\end{tabular}




\begin{tabular}{|c|c|c|}
\hline Category & & \\
\hline Housing & $\begin{array}{l}\mathbf{\square} \\
\mathbf{\square} \\
\mathbf{\square} \\
\mathbf{\square}\end{array}$ & $\begin{array}{l}\text { How important is housing quality to quality of life, both now and in the future? } \\
\text { My (family's) home is nice } \\
\text { I wish I lived in a different house } \\
\text { Total resident population per } \mathrm{km}^{2} \text { of built-up area } \\
\text { Share of total population/households living in substandard/unfit housing } \\
\text { Satisfaction of people over } 65 \text { with both home and neighbourhood }\end{array}$ \\
\hline Physical health & घ & Percentage of people who report daily physical activity \\
\hline Planning & 口 & $\begin{array}{l}\text { How important is more building in the countryside to quality of life, both now and in the } \\
\text { future? }^{\text {a }} \\
\text { Share of sustainably classified buildings of all new and renovated buildings } \\
\text { Presence of an integrated plan in the city }\end{array}$ \\
\hline Political participation & $\begin{array}{l}\mathbf{\square} \\
\mathbf{\square}\end{array}$ & $\begin{array}{l}\text { Which of the following political activities, if any, have you done during the last } 12 \text { months? }^{\text {a }} \\
\text { How much influence do you have over the quality and variety of local sporting facilities? } \\
\text { Participation rates in most recent election }\end{array}$ \\
\hline Psychological health & & $\begin{array}{l}\text { I love doing things that stimulate my senses }{ }^{a} \\
\text { I feel a sense of pride in the way my city looks and feels }{ }^{a}\end{array}$ \\
\hline Public services & घ & 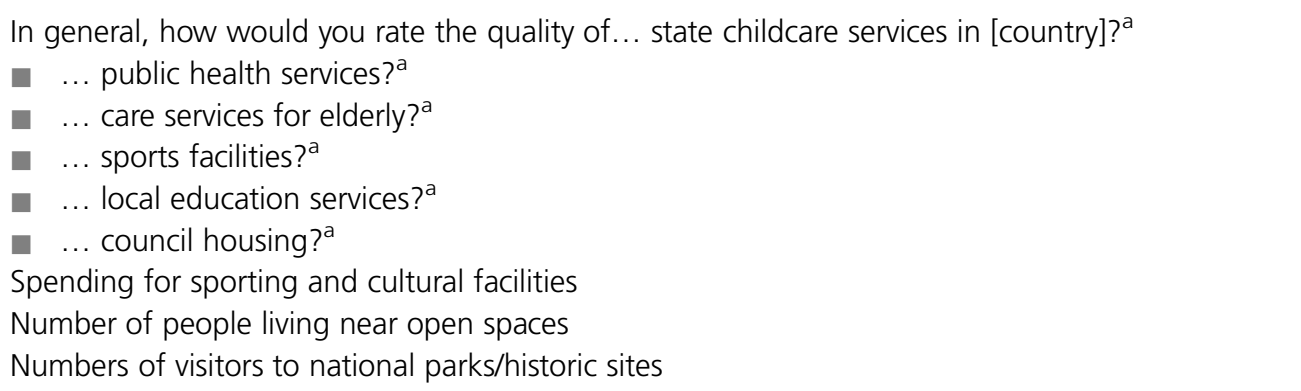 \\
\hline Social support & $\begin{array}{l}\mathbf{\square} \\
\mathbf{\square} \\
\mathbf{\square}\end{array}$ & $\begin{array}{l}\text { On average, about how many people do you have contact with in a typical week day, including } \\
\text { people you live with? } \\
\text { I feel close to the people in my local area }{ }^{a} \\
\text { My parents and I doing fun things together } \\
\text { Have you been bullied at school? } \\
\text { Percentage of people who believe people from different backgrounds get on well together in } \\
\text { their local area } \\
\text { Perceptions that people in the area treat one other with respect and dignity }\end{array}$ \\
\hline Society and tolerance & $\mathbf{\square}$ & $\begin{array}{l}\text { My local area is a place where people from different racial and ethnic and religious backgrounds } \\
\text { mix well together } \\
\text { Proportion of people who feel that racial or religious harassment is a problem in the local area } \\
\text { Proportion of people from ethnic minority groups who feel that racial or religious harassment is a } \\
\text { very or fairly big problem in the local area }\end{array}$ \\
\hline Standard of living & घ & $\begin{array}{l}\text { Household... computer access } \\
\ldots \text { Internet access } \\
\text {... broadband access } \\
\text { Proportion of the population living in the most deprived super output areas in the UK } \\
\text { Percentage of the population... that live in households that are income deprived } \\
\ldots \text { of working age that is claiming key benefits } \\
\text { Average amount of money that a household earns per year, after taxes }\end{array}$ \\
\hline
\end{tabular}




\begin{tabular}{|c|c|c|}
\hline Category & $\mathrm{Me}$ & asure \\
\hline Transportation & $\begin{array}{l}\square \\
\square \\
\square \\
\square \\
\square \\
\square \\
\square \\
\square \\
\square \\
\square\end{array}$ & 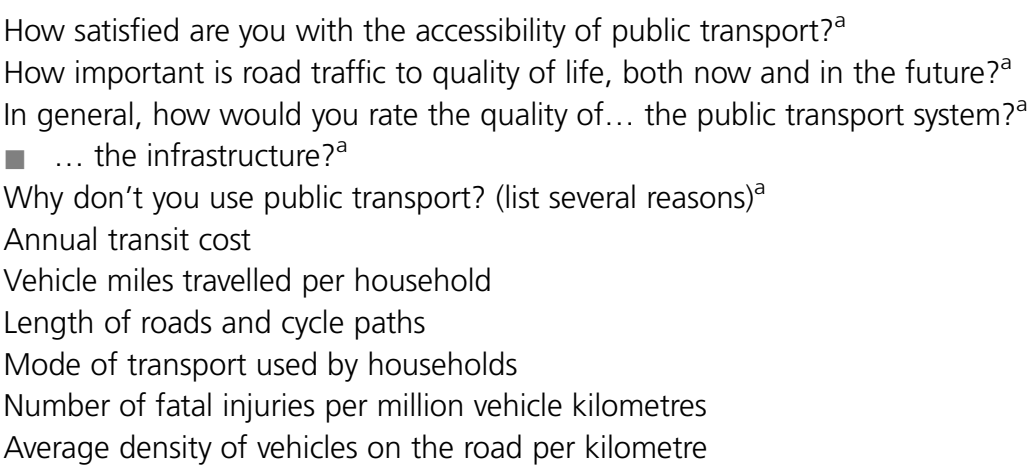 \\
\hline Work & घ & Working hours \\
\hline Work-life balance & घ & $\begin{array}{l}\text { Time/week for ... sleeping } \\
\text {... working } \\
\text {... leisure }\end{array}$ \\
\hline
\end{tabular}

${ }^{\text {a }}$ These measures are subjective well-being measures

Table 3. Continued

(i.e. the objective measures). Few studies have considered both subjective and objective measures simultaneously in terms of the relationship between well-being and the built environment (Weden et al., 2008), and none has explored the three-way relationship between well-being, low carbon and the built environment. Using both kinds of measures should result in a better reflection of the characteristics of people within cities and neighbourhoods, as well as the qualities of cities and neighbourhoods, themselves, as opposed to using just subjective or objective measures (Weden et al., 2008). Moreover, the integrated suite of measures gives decision-makers, policymakers and other stakeholders the opportunity to better understand how the built environment of their city is performing in terms of well-being and low carbon dioxide. Without the check on how well-being might be impacted, low-carbon policies may be enacted that reduce carbon dioxide but increase 'illbeing'.

While this research breaks new ground in the assessment of well-being, low carbon and the built environment in cities and neighbourhoods, it is important to acknowledge three shortcomings with this approach. First, residents of different wards may perceive their neighbourhoods quite differently. In particular, research has shown that people living in more deprived areas have more restricted socialisation patterns, have weaker social networks outside their neighbourhoods and are more inward-looking than residents living in less deprived areas (Atkinson and Kintrea (2000); compare with Atkinson and Kintrea (2001) for greater nuance of this area effect). In this sense, the neighbourhood as defined by Power and Bergin (1999) earlier in this paper may be perceived as smaller by residents of high-deprivation wards as opposed to low-deprivation residents. Thus, how residents of highas opposed to low-deprivation wards respond to and interpret the subjective well-being measures in Table 3 may reflect differences in the perceived size of their respective neighbourhoods.

Second, the overestimation and underestimation of neighbourhood effects needs more attention. Weden et al. (2008) suggest that a person's well-being may be determined just as much from his/her individual characteristics as the neighbourhood in which he/she lives. To emphasise individual factors, such as age or education, without controlling for individual-level demographic variables, means that any statistically significant findings may overestimate the impact of the neighbourhood on well-being. However, controlling for individual-level variables may lead to an underestimation of neighbourhood effects if differences in individuals (e.g. as regards age or education) translate into differences in well-being that actually originated in the neighbourhood conditions (e.g. a person receives a better education in part due to the wealth of educational resources in his/her neighbourhood). Using a large dataset may help in alleviating such over- and underestimations, generating a more statistically robust analysis. 


\section{Offprint provided courtesy of www.icevirtuallibrary.com Author copy for personal use, not for distribution}

Third, although both subjective and objective well-being measures are being used, intersubjective measures have not been considered. Particularly as the concept of low-carbon development, defined at the beginning of this paper, is perceived to be part of an organisational or system-based set of beliefs, values and culture, it will be difficult to understand the private experiences of the 'other', or 'self-contained' groups (e.g. residents living in high-deprivation wards). To some extent, however, this issue is moderated by the use of (inter)objective measures, as these measures embody the notion that perceptions and behaviours are regulated by normative systems (i.e. the collective, cultural experience in which individuals are socialised) (Moghaddam, 2003, 2010). Thus, collecting objective well-being measures can assist in better understanding the 'other'. Nonetheless, the issue of intersubjectivity and interobjectivity, pertaining to the relationship between well-being, low carbon and the built environment, requires further study.

One other way potentially to address the third shortcoming is to add further, objective data. Given the importance of the relationship between well-being and the built environment (Cooper et al., 2008, 2011; Evans et al., 2003), it makes sense to evaluate those features of the built environment that relate to well-being and low-carbon development. This is where an audit of the environment would be useful; in principle, by objectively assessing the provision of goods in an area, such as the presence, quality and access of pavements and parks, more information about the context in which people live, work and recreate becomes known (cf. Lewis (2011) for the value-laden nature of built environment audits). A good scale at which to audit the built environment, therefore, would be the neighbourhood, which primarily includes an evaluation of public spaces that people may use within a certain radius of their house. Such an integrated approach allows for both top-down ((inter) objective measures; audits) and bottom-up (subjective measures) methods, and creates a more holistic picture of wellbeing within an area (Scott, 2012) while also going some way to satisfy the issue of intersubjectivity. This is precisely what the authors are doing as part of the UK EPSRC-funded research programme grant called 'Liveable Cities'. The authors are currently undertaking three, in-depth case studies of UK cities and wards/neighbourhoods within those cities. They are collecting data using

- 50 objective well-being measures about each city (and neighbourhood where data are available) using data from different sources (e.g. ONS Neighbourhood Statistics)

- 50 subjective well-being measures by way of a wellbeing questionnaire to be administered to residents of each city (residents will be contacted through local authority ward support officers as well as community groups)

- built environment audits, containing about 60 questions, of the selected neighbourhoods within each city.
Based on previous research (see Boyko and Cooper, 2011, 2012, 2013; Cooper et al., 2008, 2009, 2011), the authors found that dwelling density and deprivation were important issues in the relationship between well-being and the built environment, and wanted to understand whether and how low-carbon development played a role in that relationship. They have chosen neighbourhoods within the selected cities that differ with respect to density and deprivation, creating four, distinct places in which to collect data: a low-density, low-deprivation neighbourhood; a low-density, high-deprivation neighbourhood; a high-density, low-deprivation neighbourhood; and a highdensity, high-deprivation neighbourhood. Once all of the data have been collected and analysed, the authors will obtain a sense of how cities and neighbourhoods are performing in relation to well-being, low-carbon development and the built environment today. The next step in this multi-phase research inquiry will be to use scenarios-based work with other members of the 'Liveable Cities' team to consider what the future might hold for cities and neighbourhoods in terms of low-carbon development that also enhances well-being. From here, it will be possible to backcast to the present to develop designs and policies that will take us to that future: a liveable, well-being-prioritised, low-carbon tomorrow.

\section{Acknowledgements}

This work was supported by the UK Engineering and Physical Sciences Research Council under grant EP/J017698/1.

\section{REFERENCES}

Aked J, Michaelson J and Steuer N (2010) Good Foundations: Towards a Low Carbon, High Wellbeing Built Environment. New Economics Foundation, London, UK.

Anderson J (2013) Urban Wellbeing: Enabling and Motivating Flourishing in Outdoor Neighbourhood Spaces. PhD thesis, Cambridge University, Cambridge, UK.

Atkinson R and Kintrea K (2000) Owner occupation, social mix and neighbourhood impacts. Policy and Politics 28(1): 93-108.

Atkinson R and Kintrea K (2001) Disentangling area effects: evidence from deprived and non-deprived neighbourhoods. Urban Studies 38(12): 2277-2298.

Bailey R, Longhurst JWS, Hayes ET et al. (2012) Exploring a city's potential low carbon futures using Delphi methods: some preliminary findings. Journal of Environmental Planning and Management 55(8): 1-25.

Bowler DE, Buyung-Ali LM, Knight TM and Pullin AS (2010) A systematic review of evidence for the added benefits of health of exposure to natural environments. BMC Public Health 10: 456.

Boyko CT and Cooper R (2011) Clarifying and reconceptualising density. Progress in Planning 76(1): 1-61. 
Boyko CT and Cooper R (2012) High dwelling density as a sustainability solution in Lancaster. Engineering Sustainability 165(1): 81-88.

Boyko CT and Cooper R (2013) Density and decision-making: findings from an online survey. Sustainability $\mathbf{5 ( 1 0 )}$ : $4502-4522$.

Bulkeley H, Castán Broto V, Hodson M and Marvin S (2013) Introduction. In Cities and Low Carbon Transitions. Routledge, London, UK, pp. 1-10.

Cabe (Commission for Architecture and the Built Environment) (2009a) Summary: Future Health: Sustainable Places for Health and Wellbeing. Cabe, London, UK.

Cabe (2009b) Future Health: Sustainable Places for Health and Wellbeing. Cabe, London, UK.

Cabe (2009c) Hallmarks of a Sustainable City. London: Cabe, UK.

Climate Change Act 2008 (2008) Elizabeth II. Chapter 27. The Stationery Office, London, UK.

Codinhoto R, Tzortzopoulos P, Kagioglou M, Aouad G and Cooper R (2009) The impacts of the built environment on health outcomes. Facilities 27(3/4): 138-151.

Community Health Partnerships (2008) Firm Foundations for World Class Commissioning: How to Achieve Value for Money in Health and Social Care Infrastructure. Community Health Partnerships, London, UK.

Coombes MG and Wong C (1994) Methodological steps in the development of multivariate indexes for urban and regional policy and analysis. Environment and Planning $A$ 26(8): 1297-1316.

Cooper R, Boyko C and Codinhoto R (2008) DR-2: The Effect of the Physical Environment on Mental Wellbeing. Government Office for Science, London, UK.

Cooper R, Boyko CT and Cooper C (2011) Design for health: the relationship between design and noncommunicable diseases. Journal of Health Communication 16(supplement 2): 134-157.

Cooper R, Evans G and Boyko C (eds) (2009) Designing Sustainable Cities. Wiley-Blackwell, London, UK.

Coulton CJ (1995) Using community-level indicators of children's wellbeing in comprehensive community initiatives. In New Approaches to Community Initiatives: Concepts, Methods and Contexts (Connell JP, Kubisch AC, Schorr LB and Weiss CH (eds)). The Aspen Institute, New York, NY, USA, pp. 173-199.

Davison KK and Lawson CT (2006) Do attributes in the physical environment influence children's physical activity? A review of the literature. International Journal of Behavioral Nutrition and Physical Activity 3: 1-17.

Day K, Carreon D and Stump C (2000) The therapeutic design of environments for people with dementia: a review of the empirical research. The Gerontologist 40(4): 397-416.

Daykin N and Byrne E (2006) The Impact of Visual Arts and Design on the Health and Wellbeing of Patients and Staff in
Mental Health Care: A Systematic Review of the Literature. Centre for Public Health Research, University of the West of England, Bristol, UK.

DECC (Department of Energy \& Climate Change) (2009) The UK Low Carbon Transition Plan: National Strategy for Climate and Energy. The Stationery Office, London, UK.

Defra (Department for Environment, Food and Rural Affairs) (2010) Measuring Progress: Sustainable Development Indicators 2010. Defra, London, UK.

Devlin AS and Arneill AB (2003) Health care environments and patient outcomes: a review of the literature. Environment and Behavior 35(5): 665-694.

Dhakal S and Shrestha R (2010) Bridging the research gaps for carbon emissions and their management in cities. Energy Policy 38(9): 4753-4755.

Dolan P, Layard R and Metcalfe R (2011) Measuring Subjective Wellbeing for Public Policy. Office for National Statistics, London, UK.

Dolan P, Peasgood T and White M (2006) Review of Research on the Influence of Personal Wellbeing and Application to Policy Making. Defra, London, UK.

Ellis K, Baker B and Lemma A (2009) Policies for Low Carbon Growth. Overseas Development Institute, London, UK.

Evans GW, Wells NM and Moch A (2003) Housing and mental health: a review of the evidence and a methodological and conceptual critique. Journal of Social Issues 59(3): 475-500.

Fowler JH and Christakis NA (2008) Dynamic spread of happiness in a large social network: longitudinal analysis over 20 years in the Framingham Heart Study. British Medical Journal 337(a2338): 1-9.

Gomi K, Shimada K and Matsuoka Y (2010) A low-carbon scenario creation method for a local-scale economy and its application to Kyoto city. Energy Policy 38(9): 4783-4796.

Government Office for Science (2008) Foresight Mental Capital and Wellbeing Project. Final Project Report. Government Office for Science, London, UK.

Handy SL, Boarnet MG, Ewing R and Killingsworth RE (2002) How the built environment affects physical activity: views from urban planning. American Journal of Preventive Medicine 23(2S): 64-73.

Harvey D (1996) Cities or urbanization? City 1(1-2): 38-61. House of Commons Environmental Audit Committee (2012) Measuring Wellbeing and Sustainable Development: Sustainable Development Indicators. The Stationery Office, London, UK.

Houses of Parliament (2012) Measuring National Wellbeing. Postnote. The Parliamentary Office of Science and Technology, London, UK.

IPCC (Intergovernmental Panel on Climate Change) (2007) Climate Change 2007 - The Physical Science Basis. Contributions of Working Group 1 to the Intergovernmental Panel on Climate Change. Cambridge University Press, Cambridge, UK. See 
http://www.ipcc.ch/ipccreports/ar4-wg1.htm (accessed 19/06/2012).

Joseph A (2006) Health Promotion by Design in Long-Term Care Settings: 21. The Center for Health Design, Concord, CA, USA.

Kaczynski AT and Henderson KA (2007) Environmental correlates of physical activity: a review of evidence about parks and recreation. Leisure Sciences 29(4): 315-354.

Kaplan R (2001) The nature of the view from home: psychological benefits. Environment and Behavior 33(4): 507-542.

Kearns A and Parkinson M (2001) The significance of neighbourhood. Urban Studies 38(12): 2103-2110.

Kubisch AC, Weiss CH, Schorr LB and Connell JP (1995) Introduction. In New Approaches to Community Initiatives: Concepts, Methods and Contexts (Connell JP, Kubisch AC, Schorr LB and Weiss CH (eds)). The Aspen Institute, New York, NY, USA, pp. 1-21.

Kuo FE (2001) Coping with poverty: impacts of environment and attention in the inner city. Environment and Behavior 33(1): 5-34.

Lawton MP (2001) The physical environment of the person with Alzheimer's disease. Aging and Mental Health 5(supplement 1): S56-S64.

Lehmann S (2015) Low carbon cities: more than just buildings. In Low Carbon Cities: Transforming Urban Systems. Routledge, Abingdon, UK, pp. 1-56.

Lewis F (2011) Towards a general model of built environment audits. Planning Theory 11(1): 44-65.

LSE Cities (2012) Going Green: How Cities are Leading the Next Economy. LSE Cities, London School of Economics and Political Science, London, UK.

Michaelson J, Mahony S and Schifferes J (2012) Measuring Wellbeing: A Guide for Practitioners. New Economics Foundation, London, UK.

Moghaddam FM (2003) Interobjectivity and culture. Culture and Psychology 9(3): 221-232.

Moghaddam FM (2010) Intersubjectivity, interobjectivity, and the embryonic fallacy in developmental science. Culture and Psychology 16(4): 465-475.

Morita T, Robinson J, Adegbulugbe A et al. (2001) Greenhouse gas emission mitigation scenarios and implications. In Climate Change 2001: Mitigation. Contribution of Working Group III to the Third Assessment Report of the IPCC (Metz B, Davidson O, Swart R and Pan J (eds)). Cambridge University Press, Cambridge, UK.

Park RE (1925) The city: suggestions for the investigation of human behavior in the urban environment. In The City (Park RE and Burgess EW (eds)). University of Chicago Press, Chicago, IL, USA.

Platt R, Cook W and Pendleton A (2011) Green Streets, Strong Communities: What Communities Can Do for Emissions
Reductions and What Emissions Reductions Can Do for Communities. Institute for Public Policy Research, London, UK.

Power A and Bergin E (1999) Neighbourhood Management. Centre for Analysis of Social Exclusion, London School of Economics, London, UK.

Scott K (2012) Measuring Wellbeing: Towards Sustainability? Earthscan, London, UK.

Staricoff RL (2004) Arts in Health: A Review of the Medical Literature. Arts Council England, London, UK, Research report 36.

Staricoff RL, Duncan JP and Wright M (2003) A Study of the Effects of Visual and Performing Arts in Health Care. Chelsea and Westminster Hospital Arts, London, UK.

Stern N (2006) Stern Review on the Economics of Climate Change. Cambridge University Press, Cambridge, UK.

Teresi JA, Holmes D and Ory MG (2000) The therapeutic design of environments for people with dementia: further reflections and recent findings from the National Institute on Aging Collaborative Studies of Dementia Special Care Units. The Gerontologist 40(4): 417-421.

Ulrich RS, Quan X, Zimring C, Joseph A and Choudhary R (2004) The Role of the Physical Environment in the Hospital of the 21st Century: A Once-In--Lifetime Opportunity. The Center for Health Design, Concord, CA, USA.

Urry J (2011) Climate Change and Society. Polity Press, Cambridge, UK.

Urry J (2013) Cities Beyond Oil: Oil Dregs and Social Futures. Zed Books, London, UK.

Van Den Berg AE, Koole SL and Van Der Wulp NY (2003) Environmental preference and restoration: (how) are they related? Journal of Environmental Psychology 23(2): $135-146$

Weden MM, Carpiano RM and Robert SA (2008) Subjective and objective neighborhood characteristics and adult health. Social Science \& Medicine 66(6): 1256-1270.

Weinstein CS (2001) The physical environment of the school: a review of the research. Review of Educational Research 49(4): 577-610.

Wells NM (2000) At home with nature: effects of 'greenness' on children's cognitive functioning. Environment and Behavior 32(6): 775-795.

Wells NM and Evans GW (2003) Nearby nature: a buffer of life stress among rural children. Environment and Behavior 35(3): 311-330.

WHO (World Health Organization) (2011) Health in the Green Economy: Health Co-Benefits of Climate Change Mitigation. Housing Sector. WHO, Geneva, Switzerland. 